\title{
USE OF CHATBOTS IN THE EDUCATIONAL PROCESS OF A HIGHER EDUCATION INSTITUTION
}

\author{
O. O. Nalyvaiko \\ V. N. Karazin Kharkiv National University, Svobody Square 6, Kharkiv, Ukraine, 61022, \\ nalyvaiko@karazin.ua_http://orcid.org/0000-0002-7094-1047 \\ A. O. Maliutina \\ V. N. Karazin Kharkiv National University, Svobody Square 6, Kharkiv, Ukraine, 61022, \\ nalyvaiko@karazin.ua, http://orcid.org/0000-0002-2312-2583
}

\begin{abstract}
The article presents the results of theoretical and practical scientific research on the feasibility of using chatbots in the educational process. The main purpose of the study was to determine the importance of chatbots in the educational process of students of higher education institutions and to consider their current involvement and prospects in the educational process of HEls. Achieving this purpose involves a number of tasks: to provide analysis of previous studies on the use of chatbots in various fields; to find out students' awareness of chatbots and their functionality; provide information about the capabilities of chatbots for the learning process; identify prospects for the development of this tool for participants in the educational process. The authors consider the theoretical provisions of the introduction of chatbot technology in the educational process of HEls. The practical part of the study consisted of personal data obtained during the survey, which was conducted using Google services (Google Forms). 69 respondents (mostly senior students) from HEls in the Kharkiv region took part in the survey. The questionnaire consists of 10 open and closed questions. Based on the obtained results and previous research, the authors proposed ways to use chatbots in the educational process of HEls and highlighted the positive aspects of using chatbots in the educational process. Prospects for the development of learning through chatbots depend on the individual capabilities of students. Because the experience of working with modern technology among students is in most cases at a high level, so we see the involvement of chatbots as a simple and fast process that does not require large funds and resources.
\end{abstract}

Key words: chatbots, students, educational process, digital technologies, digital learning tools, communication

\section{О. О. Наливайко, А. О. Малютіна}

Харківський національний університет імені В. Н. Каразіна, майдан Свободи 6, Харків, Україна, 61022

\section{ВИКОРИСТАННЯ ЧАТ БОТІВ В ОСВІТНЬОМУ ПРОЦЕСІ ЗАКЛАДУ ВИЩОЇ ОСВІТИ}

У статті представлені результати теоретичного та практичного наукового пошуку, щодо доцільності використання чат-ботів в освітньому процесі. Основною метою дослідження було визначення значення чат-ботів у навчальному процесі для студентів закладів вищої освіти та розглянути їхню нинішню залученість та перспективи у навчальний процес закладів вищої освіти. Досягнення цієї мети передбачає низку завдань: забезпечити аналіз попередніх наукових пошуків щодо використання чат-ботів у різних сферах; з'ясувати обізнаність здобувачів про чат-боти та їх функціональність; надати інформацію про можливості чат-ботів для навчального процесу; визначити перспективи розвитку цього інструменту для учасників освітнього процесу. Авторами розглянуті теоретичні положення впровадження технології чат-ботів в освітній процес ЗВО. Практичну частину дослідження склали анкетні данні отримані у процесі опитування, яке проводилося за допомогою сервісів Google (Google Forms). У опитуванні взяли участь 69 респондентів (переважно студентів старших курсів) з ЗВО харківського регіону. Анкета складалася з 10 питань відкритого та закритого типу. На основі отриманих результатів та попередніх досліджень авторами були запропоновані шляхи використання чат-ботів в освітньому процесі 3 ВО та виділені позитивні сторони використання чат-ботів в освітньому процесі. Перспективи розвитку навчання за допомогою чат-ботів залежать від індивідуальних можливостей здобувачів. Оскільки досвід роботи з сучасними технологіями серед студентів у більшості випадків на високому рівні, тому ми бачимо чат-ботів як простий і швидкий інструмент, який не вимагає залучення великих коштів та ресурсів.

Ключові слова: чат-боти, студенти, освітній процес, цифрові технології, цифрові інструменти навчання, комунікація

(c) O. O. Nalivaiko, A. O. Maliutina, 2021 
В статье представлены результаты теоретического и практического научного поиска, о целесообразности использования чат ботов в образовательном процессе. Основной целью исследования было определение значения чат-ботов в учебном процессе для студентов высших учебных заведений и рассмотреть их нынешнюю вовлеченность и перспективы в учебный процесс высших учебных заведений. Достижение этой цели предусматривает ряд задач: обеспечить анализ предыдущей работы по использованию чат-ботов в различных сферах; выяснить осведомленность учащихся о чат-ботах и их функциональность; предоставить информацию о возможности чат-ботов для учебного процесса; определить перспективы развития этого инструмента для участников образовательного процесса. Авторами рассмотрены теоретические положения внедрения технологии чат-ботов в образовательный процесс ВУЗа. Практическую часть исследования составили анкетные данные получены в ходе опроса, проведенного с помощью сервисов Google (Google Forms). В опросе приняли участие 69 респондентов (преимущественно студентов старших курсов) с ВУЗв харьковского региона. Анкета состояла из 10 вопросов открытого и закрытого типа. На основе полученных результатов и предыдущих исследований авторами были предложены пути использования чат-ботов в образовательном процессе ВУЗа и выделены положительные стороны использования чат-ботов в образовательном процессе. Перспективы развития обучения с помощью чат-ботов зависят от индивидуальных возможностей учащихся. Поскольку опыт работы с современными технологиями среди студентов в большинстве случаев на высоком уровне, поэтому мы видим привлечение чат-ботов как простой и быстрый инструмент, который не требует больших средств и ресурсов.

Ключевые слова: чат-боты, студенты, образовательный процесс, цифровые технологии, цифровые инструменты обучения, коммуникация.

Introduction. The latest digital technologies are one of the most important elements of the modern educational system. Teachers and students who want to achieve maximum results in the educational process are obliged to make fruitful use of digital technologies. The issues of effective organization of the educational process are occupied by the opinions of many scientists and researchers $[1 ; 4 ; 8 ; 13 ; 15$; 17], a special place in this discussion is occupied by the search for effective feedback between students and teachers in the digital space. Very often we can observe situations when a student needs to know urgent information or organizational issues, and the teacher's working hours are over or there is no opportunity to get the necessary information from the monitor. The solution to such situations can be the use of chatbots (CB) as an effective tool for establishing effective communication between participants in the educational process. Although today in the system of higher education the use of CB is not so widely represented, this technology is seen as a promising and convenient tool that can be mastered and used by all participants in the educational process (teachers, students, administration of educational institutions).

Recently, scientists have been studying various aspects of introducing chatbots into the learning and interaction process. Here are some of them: created the architecture of chat bots $[1 ; 6 ; 12 ; 16]$; the use of chat bots in education [5; 8; 14]; prospects for the introduction of chatbots as a communication tool in online and offline classes $[4 ; 7 ; 11]$.
The purpose of the study is to determine the value of chatbots in the educational process of students, their current involvement and prospects.

Achieving this purpose involves a number of tasks: provide an analysis of previous work on the use of chatbots in various fields; find out students' awareness of chatbots and their functionality; provide information about the possibilities of chatbots for the educational process; identify prospects for the development of this tool for participants in the educational process.

Methods. The article used theoretical research methods: analysis, generalization, comparison. The practical part of the study consisted of a questionnaire created in the format of Google services (Google Forms). 69 respondents from V. N. Karazin Kharkiv National University and other higher education institutions of the Kharkiv region took part in the survey. The questionnaire consisted of 10 open-ended and closed-ended questions. Here is their full list:

1. Do you know what a chatbot is?

2. If yes, what do you mean by this term?

3. Have you ever used a chatbot?

4. If yes, for what purpose?

5. How much dochatbots meetyourrequirements and interests?

6. Do you think chatbots can be useful in the educational process?

7. What disciplines, in your opinion, can be fully and effectively studied with the help of chatbots? 
8. Does your university have its own chatbots? If yes, are they helpful to you?

9. If not, would you like your university to create its own chatbots?

10. Do you consider chatbots as a perspective way to learn?

Theoretical part of the research. The introduction of $\mathrm{CB}$ at the beginning of the 21st century has significantly changed the people`s way of thinking and live, as CBs are able to be present anywhere, anytime in the context of a readiness to provide assistance on a mobile phone or a computer. According to Georgescu A., the effect that chatbots can have on education will forever change humanity by introducing new educational principles developed in addition to the traditional methods used by teachers in their professional activities. Chatbots can play an important role in conveying pedagogical content and evaluating applicants, covering a wide range of subjects using multimedia content. The use of chatbots allows to significantly expand the arsenal of new approaches to the methods of assessing applicants and their training, receiving feedback from particular students in real time. CB in many cases convincingly model human behavior as an interlocutor and increase the attractiveness of technology, gaining students' trust [3].

It should be noted that CB in education is a very effective tool, but it can never replace a teacher. These words are supported by the study "Chatbots: are they really useful?" [1], where the authors state that it is important to remember about the leading role of the teacher in the educational process, and learning technology, in particular CB, can act as a reinforcing element, but not as a replacement for the teacher. One example is that when the $\mathrm{CB}$ is used to answer applicants' questions, the teacher can use the generated conversation log files to find out what the applicants have problems with, including their weaknesses. After all, the teacher can use $\mathrm{CB}$ to find problems that arise in the process of learning the material, and applicants to solve it. Unfortunately, you can't find many CBs that are actually constantly used in education. The reason for this may be that their capabilities are still not generally known and accepted by the educational community $[1 ; 10]$.

Chatbot can be used as a tool for learning and practicing a foreign language. There are many benefits of using CB as an interlocutorwhen learning a language, for example, it can allow a student to practice their language skills at any time, it does not mind repeating the same material several times, it can include both text and conversational moments.
This approach can help the student in both reading and listening. However, CB as a language tool also has several drawbacks. Chatbot's responses are often predictable, redundant, or not stored in the algorithm's memory. Most CB also detects spelling or grammar errors badly. But CB can still be useful for beginners in language learning [1].

An effective example of the use of CB in education is the experience of the University of Georgia, where CB was created based on the IBM Watson platform called "Jill Watson", which was designed specifically for processing messages on the forum of students studying computer science [3]. As a result, students were more immersed in the course and wanted to have the same opportunity in other courses. CBs can compensate for the lack of individual support from teachers, especially in the case of a large number of applicants involved in university educational process or in mass open online courses (MOOC). This approach means that CBs can help provide individual learning support with limited financial and organizational resources [9].

The using of chatbots is actively included in various areas of human activity: from calculations for economists to training for athletes. They are most in demand among young people receiving education.

The using of chatbots extends to the following areas of human activity (Fig.1):

With the development of information and digital technologies, students are becoming more and more interested in learning through interactive methods. CB is an effective digital tool that allows you to learn both individually and in pairs or groups.

The main aim in the learning process for modern youth is interest in the process, awareness of their own prospects and acquired skills. More and more students prefer gadgets to books. Therefore, there is a need to optimize the learning process for generation $\mathrm{Z}$.

$\mathrm{CB}$ is a computer program that can "communicate" with a person in text or voice mode. There are two types of CB:

1. Based on a set of commands pre-entered as algorithms for user responses.

2. Based on artificial intelligence methods. This method allows the program to solve many problems.

Students can use three types of CB:

1. Public programs on the network. These are CB that created for public use. Any user can join it. Such programs are aimed at studying specific disciplines and help to acquire the knowledge to both students and users who do not study at a university.

2. CBs are created by certain universities. These can be assistants for organizational issues or counseling programs in various disciplines. 


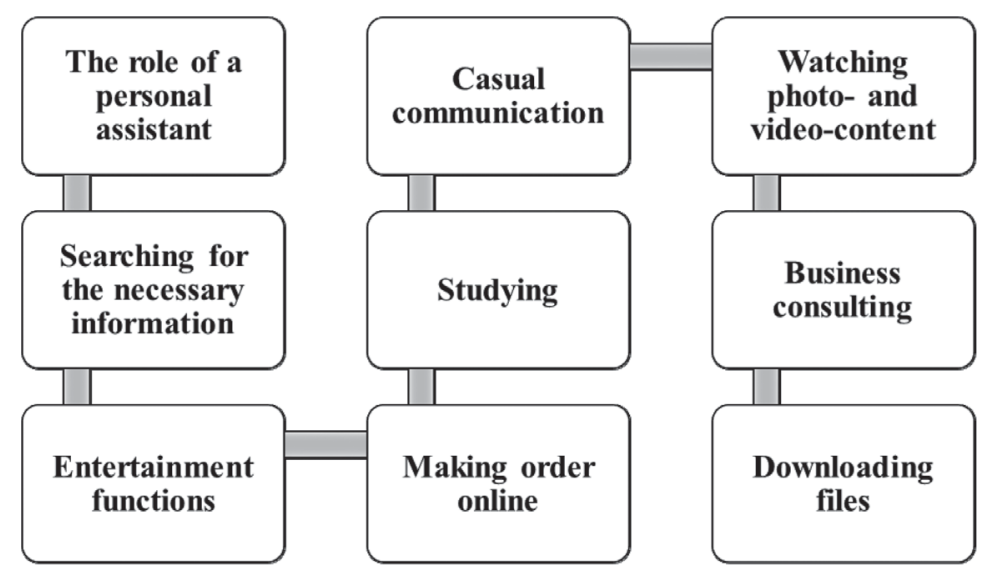

Fig. 1. Areas of using $C B$

- Most users answered that the available chatbots meet the needs at a high level.

- $\quad 62.3 \%$ consider the use of chatbots in the educational process completely appropriate, $34.8 \%$ - partially necessary.

Among the proposed disciplines, respondents identified a list of disciplines that can be most effectively studied with the help of CBs: Ukrainian, history of Ukraine, foreign languages. This is due to the humanitarian orientation of the disciplines and the convenience of presenting the material with the help of artificial intelligence (Fig.2).

A significant part of the respondents

3. Particular CBs for a teacher with an academic group. It helps to keep in touch and provide up-todate information to specific students.

Results. The study clarified the possibility of integrating CBs into the educational process and prospects for its development. This innovation helps to optimize the establishment of contact between the teacher and students, to establish communication within the university and is a convenient way to get materials. In addition, CBs are able to update knowledge and test skills. This is useful for both students and teachers. From the results of a survey conducted among students of various universities of Ukraine, we obtained the following results:

- Only $2 \%$ of respondents do not know or have not heard about chatbots.

- $72.5 \%$ have used the programs for various purposes: educational, entertainment, household, search, technical, etc. do not know about the presence of their own chatbots in their university. $72.2 \%$ want the administration of universities to create and integrate such programs into the educational process. 53.6\% of respondents consider chatbots effective and promising in the educational process. 29\% were undecided. $17.4 \%$ do not consider the use of chatbots appropriate for educational purposes. This is due to the practical orientation of some disciplines and the necessary applied practice.

Analysis of previous research and theoretical basis of the using digital means of communication and transfering the educational content, as well as surveys among students demonstrated that CBs are really a useful and effective tool in studying various humanities and social disciplines. It is a convenient tool for students, teachers and the university administration to maintain conect, control and provide the necessary materials in the learning process.

\section{What disciplines, in your opinion, can be fully and effectively studied with the help of chatbots? You can choose several answers. 69 answers}

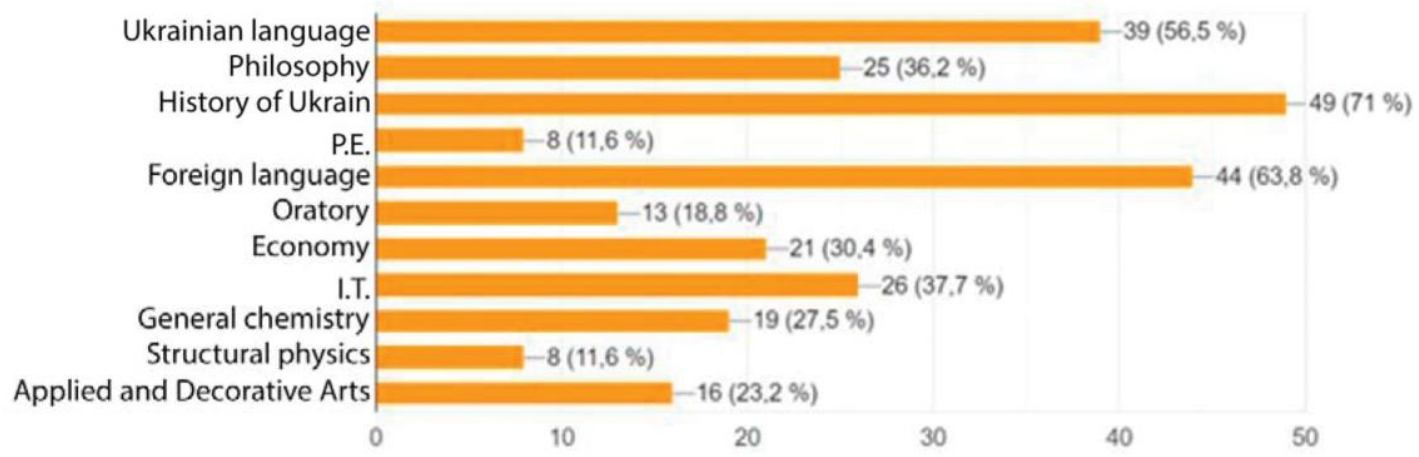

Fig. 2. The results of the survey on the appropriateness of using chatbots on various disciplines 


\section{Possibilities of using chatbots in the educational process:}

Establishing contact between teacher and student. Of course, it is not easy for a teacher to connect with all students. With the help of CBs, neither the teacher nor the students need to look for each other in the university, find out contacts and choose the time for the meeting. In the program it is convenient to write to each other in free time and not to distract another from important affairs. So everyone responds when he has an opportunity, and contact is established without much difficulty. In addition, this method of communication allows the teacher not to write individually, but to keep in touch with the whole group at once.

Material structuring. Presenting information in CBs is simple and convenient. You can divide it in parts or send the entire volume at once. It is convenient to share educational materials in several ways:

Links to textbooks or bulk files. To make it convenient for students, parts are signed and short annotations are provided.

Text in the message. It is an accessible way that allows you to read information directly in the chat at a convenient time. Eliminates the need to create personal notes.

Voice recordings. This variant is the closest to real lectures. The teacher records the material in audio format and sends it to the students.

Personal mentor. The chatbot can advise the student individually. Besides group chats with the teacher, there are many programs for additional development. Such CBs help to acquire skills and gain new knowledge.

Interactive approaches to learning. This is one of the main reasons why such programs attract students' attention. Various algorithms allow you to learn, update and consolidate knowledge in interesting ways. Testing, quizzes, surveys, and other opportunities help to make the learning process more exciting.

Evaluation of works. In chatbots, it is convenient for the teacher to get works from students and check it. For greater comfort, there are algorithms for automatic checking. In addition, you can test your knowledge in various chatbots without a teacher. Self-esteem will help to orient in the situation and develop further.

Feedback. Students can always get an answer about the work, comments, assessment or clarify the necessary questions. The program will respond the current information.

Attendance check. It is easy to involve artificial intelligence in attendance control. This is a more convenient way than classbooks or spreadsheets.
The presence or absence of students can be seen in special surveys.

Organizational channel. In addition to training, it is convenient to share information about deadlines, meetings, consultations, useful links, design samples, etc in CBs. In addition, CBs cover a wide range of functions and meet the needs of students as a source of information, regulation of organizational issues and communication between subjects.

\section{Advantages of using CBs}

\section{in the educational process:}

Accurate information. Students receive the material specifically, without unnecessary parts. Logically and accurately presented information is perceived better and assimilated more meaningfully.

Timely communication. CBs are available

around the clock. Therefore, the program can answer urgent questions at the right time. Such opportunities can be valuable when the answer needs to be given to several students at the same time. While it is difficult and impractical for a teacher to communicate in parallel with several students, chatbots can handle this. The program communicates with several users simultaneously without losing the quality of responses.

Accessibility of training. Most CBs are free and available in a variety of messengers. They are easy to install and use in your spare time. All you need is Internet access and a gadget.

It is reasonably to create $C B$ not only for teachers, but also for the university administration. In order for the CB to meet the needs of students and teachers, the following principles should be followed when creating: active reminder. Going to the site of the university, the CB must remind to the user bout himself with a greeting message; the correct algorithm for communication. Written commands for dialogue should meet the needs and provide all possible options for the development of the conversation; set of elementary buttons. For easier and more convenient use, the set of answers should be "Yes", "No". "Ask a new question", etc.

Data confidentiality. CBs should store information about users without sharing. In general, $\mathrm{CB}$ is not only a convenient way to communicate with a teacher, but also a compact library of materials, a knowledge tester and a personal assistant, which is of great importance during quarantine restrictions and distance learning.

Conclusions. Thus, it can be argued that chatbots have proven to be extremely useful as an additional or primary tool in the educational process. At this stage, chatbots are in the stage of rapid development, students and teachers are gradually joining the use of this technological development. The prospects for the development of learning us- 
ing chatbots depend on the individual capabilities of students. Since the experience of working with modern technologies among students is in most cases at a high level, therefore, we see the attraction of CBs as a simple and quick process that does not require the involvement of large funds and resources. It should be noted that design and quality of execution also affects the prospects for the introduction of chatbots. But developers are increasing these indicators, which has a positive effect on attracting chatbots to the educational process.

The most relevant chatbot for learning will be when all subjects understand that such technolo- gy is effective, and this is possible only through the introduction of this tool in their own educational experience. It takes into account the peculiarities of cognitive processes and individual differences between students.

Involving chatbots to study most disciplines with the right organization will have a positive effect on the assimilation of material, and chatbots for organizational moments will establish communication processes in a simple and convenient way. With the active spread of information and digital technologies, it is a simple, affordable and effective tool for independent and collective learning.

\section{REFERENCES:}

1. Abu, Shawar B. \& Atwell, E. (2007). Chatbots: are they really useful? Ldv forum, №22(1), 29-49.

2. Ahmad, N. A., Che, M. H., Zainal, A., Abd Rauf, M. F., \& Adnan, Z. (2018). Review of chatbots design techniques. International Journal of Computer Applications, 181(8), 7-10.

3. Ashok G., Brian C., Mithun K., Shanu S., Abhinaya S., \& Bryan W. (2015). Using Watson for Enhancing HumanComputer Co-Creativity. AAAI Symposium. 22-29

4. Clarizia, F., Colace, F., Lombardi, M., Pascale, F., \& Santaniello, D. (2018, October). Chatbot: An education support system for student. In International Symposium on Cyberspace Safety and Security (pp. 291-302). Springer, Cham.

5. Cunningham-Nelson, S., Boles, W., Trouton, L., \& Margerison, E. (2019). A review of chatbots in education: practical steps forward. In 30th Annual Conference for the Australasian Association for Engineering Education (AAEE 2019): Educators Becoming Agents of Change: Innovate, Integrate, Motivate (pp. 299-306). Engineers Australia.

6. Fernoagă, V., Stelea, G. A., Gavrilă, C., \& Sandu, F. (2018). Intelligent education assistant powered by Chatbots. In The International Scientific Conference eLearning and Software for Education (Vol. 2, pp. 376-383). "Carol I" National Defence University.

7. Fryer, L. K., Ainley, M., Thompson, A., Gibson, A., \& Sherlock, Z. (2017). Stimulating and sustaining interest in a language course: An experimental comparison of Chatbot and Human task partners. Computers in Human Behavior, 75, 461-468. http://doi.org/10.1016/j.chb.2017.05.045

8. Ghose, S., \& Barua, J. J. (2013). Toward the implementation of a topic specific dialogue based natural language chatbot as an undergraduate advisor. In 2013 International Conference on Informatics, Electronics and Vision (ICIEV) (pp. 1-5). http://doi.org/10.1109/ICIEV.2013.6572650

9. Hone, K. S., \& El Said, G. R. (2016). Exploring the factors affecting MOOC retention: A survey study. Computers \& Education, 98, 157-168.

10. Kerlyl A., Hall P., \& Bull S. (2006, December). Bringing chatbots into education: Towards natural language negotiation of open learner models. In International Conference on Innovative Techniques and Applications of Artificial Intelligence. London. Springer. (pp. 179-192). 4.

11. Kim, N. Y., Cha, Y., \& Kim, H. S. (2019). Future English learning: Chatbots and artificial intelligence. MultimediaAssisted Language Learning, 22(3), 32-53.

12. Kumar, R., \& Rose, C. P. (2011). Architecture for Building Conversational Agents that Support Collaborative Learning. IEEE Transactions on Learning Technologies, 4(1), 21-34. http://doi.org/10.1109/TLT.2010.41

13. Molnár G. and Szüts Z. (2018) "The Role of Chatbots in Formal Education," 2018 IEEE 16th International Symposium on Intelligent Systems and Informatics (SISY), Subotica, Serbia (pp. 000197-000202), doi: 10.1109/ SISY.2018.8524609.

14. Ondáš, S., Pleva, M., \& Hládek, D. (2019, November). How chatbots can be involved in the education process. In 2019 17th International Conference on Emerging eLearning Technologies and Applications (ICETA) (pp. 575-580). IEEE.

15. Ruth, D. (2006). Frameworks of managerial competence: Limits, problems and suggestions. Journal of European Industrial Training, 30(3), 206-226.

16. Sjöström, J., Aghaee, N., Dahlin, M., \& Agerfalk, P. J. (2018). Designing chatbots for higher education practice. In International Conference on Information Systems Education and Research (pp. 1-10).

17. Winkler, R. \& Söllner, M. (2018). Unleashing the Potential of Chatbots in Education: A State-Of-The-Art Analysis. In: Academy of Management Annual Meeting (AOM). Chicago. 41 p. 